\title{
THE INFLUENCE OF PERSONALITY TRAITS AND EMPLOYEE DEVELOPMENT ON THE JOB PERFORMANCE OF ENGINEERS IN MALAYSIA
}

\author{
Tony Leong Weng Beng ${ }^{1}$, Rajendran Muthuveloo \\ ${ }^{1}$ Graduate School of Business, Universiti Sains Malaysia \\ Email: tonyleongx@hotmail.com \\ ${ }^{2}$ Graduate School of Business, Universiti Sains Malaysia \\ Email: rajen789@usm.my
}

\begin{abstract}
ABSTRAK
Penelitian ini mempelajari bagaimana ciri-ciri kepribadian mempengaruhi kinerja kerja insinyur di Malaysia dan bagaimana pengembangan karyawan memastikan kinerja kerja yang optimal dalam lingkungan yang terus berubah. Sampel insinyur yang bekerja di perusahaan berbasis Elektro dan Elektronika dan hasilnya menunjukkan bahwa Extraversion dan Openness berkorelasi positif dengan Prestasi Kerja sementara Agreeableness dan Neuroticism berkorelasi negatif. Itu juga menunjukkan bahwa pengembangan karyawan memoderasi hubungan antara Kepribadian dan Prestasi Kerja untuk individu dengan tingkat Conscientiousness yang tinggi. Penemuan ini menunjukkan bahwa individu dengan ciri kepribadian yang berbeda mempersepsikan dan menanggapi upaya pengembangan karyawan secara berbeda, dengan demikian pentingnya rencana pengembangan individual.
\end{abstract}

Kata Kunci: Prestasi Kerja, Pengembangan Karyawan, Kepribadian, Model Lima Faktor, Insinyur.

\section{ABSTRACT}

This paper studies how personality traits affect the job performance of engineers in Malaysia and how employee development ensures optimal job performance in an environment of constant change. A sample of engineers working in Electrical and Electronics based companies were studied and the results showed that Extraversion and Openness were positively correlated to Job Performance while Agreeableness and Neuroticism were negatively correlated. It was also shown that employee development moderates the relationship between Personality and Job Performance for individuals with high levels of Conscientiousness. These findings show that individuals with different personality traits perceive and respond to employee development efforts differently, thus the importance of individualized development plans.

Keywords: Job Performance, Employee Development, Personality, Five-Factor Model, Engineers.

\section{INTRODUCTION}

\section{Background}

Knowledge is now an enterprise's competitive advantage (Spender, 1993). To succeed, it is important to hire, develop and retain a high performing workforce that is agile. From a hiring perspective, Barrick and Mount (1991) demonstrated that personality traits were good predictors of job performance. This led to the use of personality scorecards during job interviews. From a development perspective, Senge (1990) stressed the need for a 'learning environment' for effective employee development. Both Personality traits and employee development effort will be examined in this study.

\section{Problem statement}

Industry 4.0 uses disruptive technologies like artificial intelligence, augmented reality, additive manufacturing, big data analytics and the internet-of-things (IOT) to drive higher efficiencies. Industry 4.0 is expected to reduce production cost and widen profit margins to the tune of USD 25-45B per year by 2030 for countries of Southeast Asia alone (Tonby, Ng and Mancini, 2014). Over 1 million Malaysians, involved in manufacturing which contributes $23 \%$ of its GDP, would need to develop new skills to thrive in Industry 4.0 and engineers will play a large role in this 
transition (Motyl, Baranio, Uberti, Speranza and Filippi (2017). The target of this research is to help managers develop higher performing, adaptable engineers to keep Malaysian factories competitive in the Industry 4.0 era.

Most Personality - Job Performance studies were done in western countries, with only limited studies done in Malaysia. This poses a gap, as it has been shown that cultural perspectives do affect Occupational Citizenship Behavior which is a dimension of Job Performance (Fahr, Zhong \& Organ, 2004). Besides cultural factors, none of the studies in Malaysia have covered engineering professionals. In fact, there have been very few studies done on the Personality - Job Performance relationship on engineers across the globe. This darth of information on engineering professionals in Malaysia provided the motivation for this study.

\section{LITERATURE REVIEW}

Details of key variables, underpinning theory and the research model used in this study are presented in the following sections.

\section{Job Performance}

Job performance has traditionally been linked to task performance (Wen, Muthuveloo and Ping, 2017). It is a measure of how effectively an individual performs the activities contributing to the economic well-being of the organization.

Job Performance is a multi-dimensional construct and Viswesvaran and Ones (2000) suggested that it comprises of Task Performance (getting the job done), Contextual Performance (Organizational Citizenship Behavior) and Counterproductive Work Behavior (CWB). CWB can take the form of deliberate acts of sabotage or more subtle forms, like failing to do the job correctly or failing to follow instructions (Muthuveloo, Basbous, Ping and Long, 2013).

\section{Personality Traits}

Personality is defined as a consistent pattern of behaviors demonstrated by an individual as a result of his or her personal values, experience, feelings and desires derived over time (Revelle, W, Condon, D.M., 2015). In this study, the Five Factor model was chosen to describe personality as it is widely used, allowing data comparison with other studies when necessary. The personality traits described by the Five Factor model are as follows:

Conscientiousness is a trait of being cautious and vigilant. It implies a desire to perform a task well and takes seriously the obligation to others. Extraversion captures an individual's comfort level with relationships. People high in extraversion enjoy activities that involve large social gatherings and tend to work better in groups. Agreeableness refers to an individual's likeability or ability to accommodate the needs of others. Neuroticism measures a person's ability to withstand stress. People with high neuroticism tend to express negative feelings and fear, while people with low neuroticism are self-confident, secure and calm. People high in openness to experience tend to be aware of their own feelings, are intrinsically curious and open to changes.

\section{Employee Development}

Three factors are needed for effective employee development. Firstly, an individual needs to be self-motivated to develop oneself (Muthuveloo and Teoh, 2017). Secondly, they need organizational support for development. Thirdly, the individual needs to actively participate in the development activity. 


\section{Underpinning Theory}

The linkage between personality traits and job performance is best explained by the TraitActivation Theory. When behavioral traits that improve job performance are exhibited, the individual receives positive workplace reinforcement which encourages further display of such behavior forming a virtuous cycle of excellence. This is supported by the I-TOP Strategic Agility model proposed by Muthuveloo, R., \& Ping, T. A., (2013).

\section{Research Model}

Based on the research gap and underpinning theory, the following conceptual framework was proposed. Applying the Trait Activation Theory, Job Performance was proposed as the dependent variable while Personality an independent variable.

In the current environment of constant change, Employee Development was proposed as a moderator between Personality and Job Performance. This is supported by Kennedy \& King (2005) who pointed out that employees were increasingly concerned about their skills being obsoleted and Lee and Brugold (2003) who stated that an organization's outcome was influenced by its commitment to employee development. Rousseau's (1995) psychological contract theory similarly states that employees perceive a long term employer-employee relationship when offered a challenging job together with the training and development opportunities needed for success.

The conceptual model for this research is shown in Figure 1.

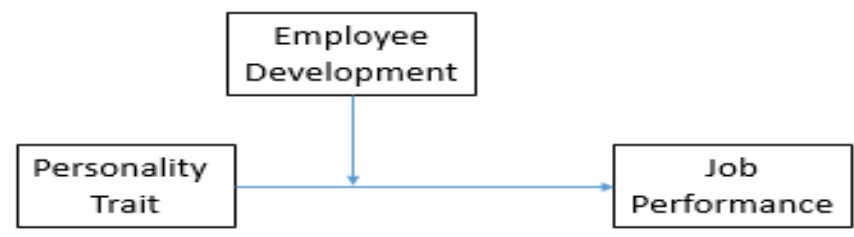

Figure 1: Conceptual Framework used.

\section{Research Hypotheses}

The relationship between key variables and appropriate hypotheses are formulated as below:

Relationship between Personality and Job Performance: Based on the trait activation theory, an individual with a given set of personality traits is best suited for a given job type. Barrick and Mount (2005) posits that personality affects motivation by influencing how much effort is put into work. When an individual's personality is aligned to the job needs, job peformance improves. This gives rise to the following hypothesis.

\section{Hypothesis 1: Personality has a positive significant correlation to Job Performance}

Employee Development as a moderator between Personality Trait and Job Performance: In an environment of change, employees need to be involved in learning and development. An employee who does not learn new skills runs the risk of being obsolete in time. Based on the above, employee development was assessed as a moderator in the personality trait - job performance relationship, leading to the following hypothesis.

Hypothesis 2: Employee Development moderates positively and significantly the relationship between Personality and Job Performance 


\section{RESEARCH METHODOLOGY}

The research methodology used in this study are detailed in the following sections.

\section{Research Design}

This research utilized a quantitative, cross-sectional, correlational study conducted one time, using a hypothesis testing approach to study the relationship between Personality, Employee Development and Job Performance. A questionnaire was designed and pre-tested before starting the main survey. The survey results were checked for validity and then used to determine the structural model path coefficients. These coefficients were then used for hypotheses testing. Following this, the moderating effect of Employee Development was assessed.

\section{Population and sample size}

The population studied were professionals working in engineering roles in electrical and electronics $(\mathrm{E} \& \mathrm{E})$ based companies in Malaysia. Their engineering roles include research \& development, design, manufacturing, equipment \& process maintenance, technical staff and project management and sales \& service support. The E\&E sector was chosen as it is the leading manufacturing sector in Malaysia, contributing to $36.6 \%$ of the country's exports and providing 25.3\% of its employment. (MIDA, Malaysian Investment Development Authority, 2016).

Hair, Sarstedt, Ringle \& Mena (2012) proposed a minimum sample size at least ten times larger than the number of variables studied. As there are 6 independent variables in this study, the minimum number of samples needed would be 60 . For good measure, it was decided to obtain at least 200 samples, taking into consideration that some responses may be unusable.

\section{Sampling technique and data collection method}

This study used the convenience sampling method which involves samples from a part of the population that is close at hand. While it may not be as representative as a full random sampling method, it is practical and quick. To minimize the effect of biased sampling, data was collected from multiple companies across different geographical regions in Malaysia. Google Forms was used to collect respondent feedback.

\section{Measurement Instruments}

To measure job performance, the Individual Work Performance Questionnaire (IWPQ) developed by Koopman, L et. al. (2011) was used. It is based on a three-dimensional conception framework for Job Performance: Task Performance, Contextual Performance and CounterProductive Work Behavior. The Big Five Inventory (BFI) developed by John and Srivastava (1999) which assessed the 5 personality traits using 44 questions was chosen for this research.

The Dimensions of Learning Organization Questionnaire (DLOQ) was selected to measure the availability of an environment conducive for employee development. It is based on the learning framework developed by Watkins and Marsick (1993) which specifies the 7 characteristics required by a learning organization, i.e. continuous learning, dialog and inquiry, team learning, learning systems, empowerment, connections and strategic leadership. All questionnaires selected used a 5-point Likert scale and are widely used and have been proven reliable.

\section{Data analysis techniques}

Partial Least Squared (PLS) was used in data analysis. PLS is a Structural Equation Modeling (SEM) technique that uses a prediction-oriented variance based approach that emphasizes endogenous target constructs in the model and maximizes their explained variance (Hair, 
Sarstedt, Ringle \& Mena, 2012). SmartPLS-SEM version 3.2.7 was used for PLS data analysis, while IBM-SPSS Version 24.0 was used for descriptive statistical analysis.

\section{RESULTS AND DISCUSSION}

\section{Results}

From the 350 invitations sent out, 212 complete responses were received from a wide sociodemographic spread as shown in Table 1.

Table 1: Socio-demographic of respondents

\begin{tabular}{|c|c|c|c|c|c|}
\hline Gender & $\begin{array}{l}\text { Male: } \\
76 \%\end{array}$ & $\begin{array}{l}\text { Female: } \\
24 \%\end{array}$ & & & \\
\hline Age & $\begin{array}{l}\text { <30years: } \\
34 \%\end{array}$ & $\begin{array}{l}30-40 \text { years: } \\
24 \%\end{array}$ & $\begin{array}{c}40-50 \text { years: } \\
16 \%\end{array}$ & $\begin{array}{l}>50 \text { years: } \\
26 \%\end{array}$ & \\
\hline $\begin{array}{l}\text { Education } \\
\text { (Degree) }\end{array}$ & $\begin{array}{l}\text { Bachelor: } \\
69 \%\end{array}$ & $\begin{array}{l}\text { Masters: } \\
22 \%\end{array}$ & $\begin{array}{c}\mathrm{PhD}: \\
7 \%\end{array}$ & $\begin{array}{l}\text { Diploma: } \\
2 \%\end{array}$ & \\
\hline Job Role & $\begin{array}{l}\text { R\&D: } \\
31 \%\end{array}$ & $\begin{array}{l}\text { Manufacturing } \\
: 26 \%\end{array}$ & $\begin{array}{c}\text { Construction: } \\
12 \%\end{array}$ & $\begin{array}{cc}\text { Equipment/IT: } & \text { Management: } \\
11 \% & 10 \% \\
\end{array}$ & $\begin{array}{l}\text { Technical } \\
\text { Sales:9\% }\end{array}$ \\
\hline Job Title & $\begin{array}{l}\text { Engineer: } \\
\quad 41 \%\end{array}$ & $\begin{array}{c}\text { R\&D: } \\
6 \%\end{array}$ & $\begin{array}{c}\text { Manager: } \\
38 \%\end{array}$ & $\begin{array}{c}\text { Senior } \\
\text { Managers: } \\
15 \%\end{array}$ & \\
\hline
\end{tabular}

As there are 5 factors in Personality, Hypothesis 1 was broken into 5 sub-hypotheses. It was found that Extraversion and Openness were positively correlated to Job Performance while Neuroticism and Agreeableness were negatively correlated. Details are summarized in Table 2.

Table 2: Results of testing Hypothesis 1

\begin{tabular}{lcccc}
\hline \multirow{2}{*}{ Personality } & \multicolumn{4}{c}{ Correlation to Job Performance } \\
\cline { 2 - 5 } & Beta & p-Value & Correlation & Significant? \\
\hline Agreeableness & -0.14 & 0.02 & $(-)$ & $\mathrm{Y}$ \\
Conscientiousness & 0.11 & 0.07 & $(+)$ & $\mathrm{N}$ \\
Extraversion & 0.25 & 0 & $(+)$ & $\mathrm{Y}$ \\
Openness & 0.36 & 0 & $(+)$ & $\mathrm{Y}$ \\
Neuroticism & -0.29 & 0.001 & $(-)$ & $\mathrm{Y}$ \\
\hline
\end{tabular}

Statistically valid with $\mathrm{p}<0.05$

Hypothesis 2 was similarly broken into 5 sub-hypotheses based on the 5 factors in Personality. It was found that Employee Development positively and significantly moderated the relationship between Conscientiousness and Job Performance. Employee Development did not moderate the relationship between Agreeableness, Openness, Extraversion, Neuroticism and Job Performance. See Table 3 below.

Table 3: Results of testing Hypothesis 2

\begin{tabular}{lccc}
\hline \multirow{2}{*}{ Personality } & \multicolumn{3}{c}{ Employee Development as moderator between Personality \& Job } \\
& \multicolumn{3}{c}{ Performance } \\
\cline { 2 - 4 } & $\mathrm{b}$ & $\mathrm{p}-$-Value & Moderator? \\
\hline Agreeableness & -0.03 & 0.31 & $\mathrm{~N}$ \\
Conscientiousness & 0.174 & 0.02 & $\mathrm{Y}$ \\
Extraversion & -0.14 & 0.23 & $\mathrm{~N}$ \\
Openness & -0.21 & 0.10 & $\mathrm{~N}$ \\
Neuroticism & 0.12 & 0.11 &
\end{tabular}

Statistically valid with $\mathrm{p}<0.05$ 


\section{Discussion}

The findings of this research are stated as follows:

The positive correlation between Openness and Extraversion and negative correlation between Neuroticism with Job Performance were expected as it has been seen in other work group studied. Somewhat unexpected was the finding that Agreeableness was negatively correlated to engineering Job Performance. This finding departs from the findings of Frei and McDaniel (1997) who found that customer service personnel have high agreeableness and conscientiousness.

One possible explanation may be that while customer service personnel are expected to address customer concerns, engineers are expected to follow relatively rigid rules and logical procedures to ensure that the products and services they provide meet statutory and customer required safety and quality specifications. Engineers frequently work with immutable laws of Physics that may not allow them to be as cooperative nor agreeable with their stakeholders. Engineers have to stand up and disagree when non-practical or non-optimal requests are made of them. This may explain why engineers with high agreeability may have lower job performance.

Another interesting finding was that the statistical significance of the hypothesis that Conscientiousness was positively correlated to Job Performance was marginally lower than the 95\% expectation (93\% actual). It is counter-intuitive that a personality trait that is described as careful, diligent, dependable, self-disciplined would not be positively correlated to job performance. A possible explanation for this may be related to the work of LaHuis, et al (2005) who identified that personality traits (particularly Conscientiousness) may not have a linear relationship with Job Performance. On the low end of Conscientiousness, an individual is seen as lazy or careless on the job, while on the high end of conscientiousness, an individual may be seen as over-careful and rigid. They posit that individuals with moderate scores of Conscientiousness will provide the best job performance.

The study also showed that Employee Development was a moderator for the Conscientiousness Job Performance relationship but did not moderate the relationships between Agreeableness, Extraversion, Openness and Neuroticism with Job Performance. Conscientious individuals are responsible, hardworking, self-disciplined and organized (Barrick \& Mount, 1991) and are likely to work harder when offered training opportunities.

\section{Research Contribution}

From a theoretical perspective, this study has proposed and tested a theoretical model linking Personality, Job Performance and Employee Development. Extraversion and Openness were found to be positively correlated while Agreeableness and Neuroticism were negatively correlated to Job Performance. Secondly, this study confirmed that Employee Development moderated the Personality - Job Performance relationship, but only for individuals with high levels of Conscientiousness.

From a practitioner's perspective, this reserach highlighted 2 key learnings. Firstly, individuals with different personality types perform their jobs differently and supervisors can help each of their subordinate adjust their behaviors to improve Job Performance. Secondly, supervisors and managers should be aware that employee development has impact on job performance and different personality types perceive and respond to development efforts differently, underlining the need for individualized versus generic employee development activities. 


\section{Research Limitations}

Two limitations were identified in this research. Firstly, for practical reasons, this researh relied on a self-reporting survey which could add to common method bias. Secondly, the research used a convenience sampling technique which could introduce biased data.

\section{SUMMARY \& RECOMMENDATIONS}

The two objectives of determining if there was correlation between Personality and Job Performance among Malaysian engineering professions and if Employee Development moderates the relationship between Personality and Job Performance were met.

Firstly, Extraversion and Openness were found to positively correlate to job performance while Neuroticism and Agreeableness were negatively correlated.

Secondly, it was shown that employee development is a moderator between Personality and Job Performance for individuals with high Conscientiousness. The theoretical and practitioner contributions, limitations and areas for further research were also presented.

Based on the limitations listed above, future researchers may want to look into getting $360^{\circ}$ responses for personality trait and job performance measurements. Secondly, they could refine the target population to one where a random statistical sampling method can be used.

Additionally, the finding that Employee Development only moderates the Personality - Job Performance relationship for individuals with high Conscientiousness deserves further research. This finding may indicate that there are other variables besides Employee Development that moderate the Personality - Job Performance relationship.

\section{REFERENCES}

Barrick, M.R. \& Mount, M.K., (1991). The Big Five Personality Dimensions and Job Performance: A Meta-Analysis. Personnel Psychology, 44: 1-26.

Barrick, M.R. \& Mount, M.K. (2005) Yes, Personality Matters: Moving onto More Important Matters, Human Performance Vol 18(4) pp 359-372.

Fahr, J.L., Zhong, C.B., Organ, D.W., (2004) Organizational Citizenship Behavior in the People's Republic of China, Organization Science, Vol 15 No. 2 April 2004, pp 241-253

Frei, R. L., \& McDaniel, M. A. (1997). Validity of customer service measures in personnel selection: A review of criterion and construct evidence. Human Performance, Vol 11, pp $1-27$.

Hair, J. F., Sarstedt, M., Ringle, C. M., \& Mena, J. A. (2012). An assessment of the use of partial least squares structural equation modeling in marketing research. Journal of the academy of marketing science, 40(3), 414-433.

John, O. P., \& Srivastava, S. (1999). The Big-Five trait taxonomy: History, measurement, and theoretical perspectives. In L. A. Pervin \& O. P. John (Eds.), Handbook of personality: Theory and research (Vol. 2, pp. 102-138). New York: Guilford Press.

Kennedy, P. W., \& King, I. P. (2005). Economic progress and skill obsolescence with network effects. Economic Theory, 26, 177-201

Koopmans, L., Bernaards, C.M., Hildebrandt, V.H., Schaufeli, W.B., deVet, H.C.W., van der Beek, A.J., (2011) "Conceptual Frameworks of Individual Work Performance - A Systematic Review", American College of Occupational and Environmental Medicine. (DOI: 10.1097/JOM.0b013e31822a763. 
LaHuis, D. M., Martin, N. R. \& Avis, J. M. (2005). Investigating nonlinear conscientiousnessjob performance relations for clerical employees. Human Performance, 18 (3), 199-212.

Lee, C. H., \& Bruvold, N. T. (2003). Creating value for employees: Investment in employee development. International Journal of Human Resource Management, 14, 981-1000.

Motyl, Barbara \& Baronio, Gabriele \& Uberti, Stefano \& Speranza, Domenico \& Filippi, Stefano. (2017). How will Change the Future Engineers' Skills in the Industry 4.0 Framework? A Questionnaire Survey. Procedia Manufacturing. 11. 1501-1509. 10.1016/j.promfg.2017.07.282.

Muthuveloo, R., Basbous, O.K., Teoh, A.P., Long, C.S. (2013) Antecedents of Employee Engagement in the Manufacturing Sector, American, Journal of Applied Sciences 10(12), 1546-1552, 2013.

Muthuveloo, R. \& Teoh, A.P. (2013). Achieving business sustainability via I-Top Model, American Journal of Economics and Business Administration, 5(1), pg 15-21

Muthuveloo, R. \& Teoh, A.P. (2017). RACE: The Theory of Emergence for Strategic Entrepreueurship, International Review of Management and Marketing, 7(1), pg 164-168

Podsakoff, P.M., MacKenzie, S.B., Paine, J.B., Bachrach, D.G. (2000). Organizational Citizenship Behaviors: A Critical Review of the Theoretical and Empirical Literature and Suggestions for Future Research. Journal of Management Vol 26, Issue 3. Pp. 513-563.

Revelle, W., Condon, D.M. (2015) A model for personality at three levels, Journal of Research in Personality, 56 (2015) pp 70-81.

Rousseau (1995). Psychological Contracts in Organizations: Understanding written and unwritten agreements. Sage Publication, California.

Senge, P. (1990). The fifth discipline: The art and practice of the learning organization. New York: Doubleday Currency.

Spender, J.C. (1993). Competitive advantage from tacit knowledge? Unpacking the concept and its strategic implications, Academy of Management Best Papers Proceedings, August, pp. $37-41$.

Tonby, O., J. Ng and M. Mancini (2014), Understanding ASEAN: The manufacturing opportunity, McKinsey Productivity Sciences Center

Viswesvaran, C., \& Ones, D. S. (2000). Perspectives on models of job performance. International Journal of Selection and Assessment, 8, 216-226.

Watkins, K. E., \& Marsick, V. J. (1993). Sculpting the learning organization: Lessons in the art and science of systemic change. San Francisco, CA: Jossey-Bass.

Wen, C.K., Muthuveloo, R. \& Teoh, A.P. (2017) The Effects of Heart Count on Employee's Perception on Separation. Journal of Engineering Applied Science, 12 (2) , 248-25. 